\title{
IGF2 role in adrenocortical carcinoma biology
}

\author{
Sofia S. Pereira ${ }^{1,2,3} \cdot$ Mariana P. Monteiro ${ }^{3}$ Madalena M. Costa ${ }^{3} \cdot$ Ângela Moreira $^{3} \cdot$ Marco G. Alves $^{4,5}$. \\ Pedro F. Oliveira ${ }^{1}$ Ivana Jarak ${ }^{5}$ Duarte Pignatelli $\mathbb{C}^{1,2,6}$
}

Received: 10 March 2019 / Accepted: 20 July 2019 / Published online: 4 August 2019

(c) The Author(s) 2019

\begin{abstract}
Purpose Clinical outcomes of adrenocortical carcinomas (ACC) could be improved by using novel treatment targets based on the recent advances of tumor biology knowledge. Insulin-like growth factor 2 (IGF2) protein expression is usually 8-80 fold higher in ACC when compared to normal adrenal glands (N-AG) or adrenocortical adenomas (ACA), despite the fact that the biological features of high vs. low IGF2 expressing ACC have not yet been well characterized. Our goal was to understand the IGF2 role in ACC biology by focusing in several cancer hallmarks, including cell proliferation, viability, invasion, and metabolism.

Methods IGF2 immunohistochemistry expression was evaluated in ACC $(n=13)$, non-functioning adrenocortical adenoma (ACAn) $(n=14)$, and N-AG $(n=9)$. The effects of IGF2 $(50,100 \mathrm{ng} / \mathrm{mL})$ in cell proliferation, viability, invasion, and metabolism, as well as in MAPK/ERK and mTOR pathways activation and N-cadherin expression, were evaluated in the ACC human cell line H295R.

Results IGF2 expression was increased in ACC compared to ACAn and N-AG. Exposure to $100 \mathrm{ng} / \mathrm{mL}$ of IGF2 increased H295R cell proliferation and viability. mTOR inhibition reverted IGF2 triggered cell proliferation and viability while MEK/ MAPK/ERK inhibition only reverted IGF2 effects on cell proliferation. IGF2 at a $50 \mathrm{ng} / \mathrm{mL}$ concentration increased the glycolytic flux and decreased glutamine consumption.

Conclusions IGF2 is an excellent marker to differentiate ACC from ACAn. In addition, IGF2 was demonstrated to influence adrenocortical cancer cell proliferation, metabolism, and viability, but not the cell invasion. These data support that different IGF2 concentrations in ACC can be responsible for different biological behaviors of ACC.
\end{abstract}

Keywords Adrenocortical tumors $\cdot$ Adrenocortical carcinomas $\cdot$ IGF2 $\cdot$ Hallmarks of cancer

\section{Introduction}

Adrenocortical tumors (ACT) are common adrenal cortex tumors that affect $3-10 \%$ of the adult population [1]. The

Supplementary information The online version of this article (https:// doi.org/10.1007/s12020-019-02033-5) contains supplementary material, which is available to authorized users.

Duarte Pignatelli

dpignatelli@ipatimup.pt

1 Instituto de Investigação e Inovação em Saúde (I3S), Universidade do Porto, Porto, Portugal

2 Institute of Molecular Pathology and Immunology of the University of Porto (IPATIMUP), Porto, Portugal

3 Endocrine, Cardiovascular \& Metabolic Research, Department of Anatomy, Multidisciplinary Unit for Biomedical Research majority of ACT are benign, non-functioning and incidentally discovered during imaging studies performed for unrelated clinical reasons [2]. In contrast to adrenocortical adenomas (ACA), adrenocortical carcinomas (ACC) are rare, the majority are diagnosed in an advanced stage and usually have a poor prognosis [1]. Detailed knowledge of molecular alterations that underlie the malignant transformation of benign cells, as well as the identification of the specific cell cycle alterations found in cancer cells that are

(UMIB), ICBAS, University of Porto, Porto, Portugal

4 Biology and Genetics of Reproduction, Department of Microscopy, Laboratory of Cell Biology, Multidisciplinary Unit for Biomedical Research (UMIB), ICBAS, University of Porto, Porto, Portugal

5 Health Sciences Research Center, University of Beira Interior, Covilhã, Portugal

6 Department of Endocrinology, Hospital S.João, Porto, Portugal 
associated with enhanced survival, have not only allow the identification of new diagnostic and prognostic tools but also provides the potential to disclose novel treatment targets. The IGF2 system is one of the key molecular mechanisms that was recurrently described to be involved in ACC pathophysiology [3-7].

IGF2 is a growth factor secreted mainly by the liver but also in smaller amounts in the majority of tissues where it acts in an autocrine or paracrine way. IGF2 actions are mediated by the IGF1 receptor (IGF1R), insulin receptor (IR) and IGF2 receptor (IGF2R) [8, 9]. IGF2 activates tyrosine kinase receptors that in turn lead to mitogen-activated protein kinase (MAPK) and phosphatidylinositol 3-kinase (PI3K)/Akt pathways activation. Activated Akt is then able to trigger the subsequent activation of the mammalian target of rapamycin (mTOR) pathway. MAPK, PI3K/Akt/mTOR pathways are well-described mechanisms involved in proliferation, survival, and metastasis of cancer cells [8-10].

IGF2 overexpression was previously described as responsible for increased proliferation of ACC cells [11]. However, despite being increased in the majority of the tumors, IGF2 expression can be highly variable in ACC cells. IGF2 mRNA expression was found to be 10-20 fold higher in ACC compared to normal adrenal glands or ACA, while IGF2 protein expression was described to be 8-80 fold greater in ACC than in normal adrenal glands or ACA [11-16]. Therefore, our goal was to extend the understanding of the IGF2 role in ACC evaluating the expression of IGF2 in the adrenocortical tumors and the paracrine effects of IGF2 in the proliferation, viability, invasion, and metabolism of ACC cells.

\section{Materials and methods}

\section{Adrenal tissue}

Adrenal tumor samples were obtained from patients with ACT $(n=27)$, comprising 13 ACC and 14 non-functioning adenomas (ACAn). Normal adrenal glands (N-AG) $(n=9)$ retrieved during nephrectomy performed for urologic conditions from patients without adrenal pathology were used as controls. A summary of the patient's clinical features and tumors characteristics is present in Table 1 . The study was approved by the Ethics Committee of the Centro Hospitalar São João - Porto, Portugal. The participants provided their written informed consent to tumor storage in the tumor bank of the Department of Pathologic Anatomy-Centro Hospitalar São João, Porto, for later research use.

\section{Immunohistochemistry (IHC) and data analysis}

IHC was performed in $3 \mu \mathrm{m}$ formalin-fixed paraffinembedded tissue sections mounted on adhesive microscope
Table 1 Patients clinical features and tumors characteristics

\begin{tabular}{lll}
\hline & ACC $(n=13)$ & $\begin{array}{l}\text { ACAn } \\
(n=14)\end{array}$ \\
\hline Median age in years (Range) & $46(27-59)$ & $49(23-76)$ \\
Tumor size (mm) & $188 \pm 98$ & $38 \pm 23$ \\
Weiss score & $>4$ & $\leq 2$ \\
Tumors functionality (Functioning/ & $8 / 5$ & $0 / 14$ \\
non-functioning) & & \\
ENSAT stage (I, II, III, IV) & $(0 / 1 / 8 / 4)$ & NA \\
p53 (\% stained area) & $5.3 \pm 1.91$ & $3.5 \pm 0.45$ \\
$\beta$-catenin localization (M:C:N) & $3: 8: 2$ & $0: 8: 6$ \\
\hline
\end{tabular}

$A C C$ adrenocortical carcinomas, $A C A n$ non-functioning adrenocortical adenoma, NA field is not applicable, ENSAT European Network for the Study of Adrenal Tumours, \# $M$ only membrane, $C$ Membrane + cytoplasm, $N$ Membrane + cytoplasm + nucleus

slides. Sections were deparaffinized, rehydrated in graded alcohols and underwent antigen retrieval performed by microwave treatment in $0.01 \mathrm{M}$-citrate buffer at $\mathrm{pH} 6.0$, during $9 \mathrm{~min}$. The sections were then incubated overnight at $4{ }^{\circ} \mathrm{C}$ with the primary antibody against IGF2 (Table 2). The detection of the immune reaction was performed using the avidin-biotin-peroxidase method (1:100; Vector Laboratories, Inc., Peterborough, UK). DAB (3,3'- diaminobenzidine) was used as chromogen and hematoxylin as nuclear counterstaining. Placental tissue was used as positive control, while omission of the primary antibody from incubation was used as negative control.

Immunohistochemistry for $\mathrm{p} 53$ and $\beta$-catenin staining was performed as previously reported [17].

From each section slide, a minimum of 10 microphotographs were taken (Leica EC3 camera, Leica, Germany) and images were analyzed using the software ImageJ (originated at the National Institutes of Health, USA) that allows separation of the stained area from the total area in order to calculate the percentage of the area stained both for IGF2 and p53. The staining for $\beta$-catenin exhibited different cell distributions (cell membrane, cytoplasm, and nucleus), and so the distribution of $\beta$-catenin staining was evaluated by direct observation.

\section{Cell culture}

Human adrenocortical carcinoma cell line (H295R) obtained from CLS Cell Lines Service GmbH (Eppelheim, Germany) was cultured in Dulbecco's Modified Eagle Medium: Nutrient Mixture F-12 (DMEM/F12; SigmaAldrich, St Louis, MO, USA) supplemented with $0.365 \mathrm{~g} / \mathrm{L}$ of L-glutamine (Sigma-Aldrich, St Louis, MO, USA), $10 \mathrm{~mL} / \mathrm{L}$ of penicillin-streptomycin (Sigma-Aldrich, St Louis, MO, USA), $2.5 \%$ of NuSerum (BD Bioscience, San Jose, CA) and $1 \%$ of Insulin-Transferrin-Selenium Premix 
Table 2 Antibodies used in this study

\begin{tabular}{|c|c|c|c|}
\hline Antibodies & Source & Reference and vendor & Dilution \\
\hline \multicolumn{4}{|c|}{ Primary antibody used in Immunohistochemistry } \\
\hline IGF2 & Rabbit & $\begin{array}{l}\text { Ref. ab9574; Abcam, Cambridge, United } \\
\text { Kingdom }\end{array}$ & $1: 100$ \\
\hline$\beta$-catenin & Rabbit & Ref. 424A-14; Cell Marque, Rocklin, CA, USA & $1: 500$ \\
\hline $\mathrm{p} 53$ & Rabbit & Ref. 453M-94; Cell Marque, Rocklin, CA, USA & $1: 100$ \\
\hline \multicolumn{4}{|c|}{ Primary antibody used in Immunofluorescence } \\
\hline $\operatorname{BrdU}$ & Mouse & $\begin{array}{l}\text { Ref. sc-32323; Santa Cruz Biotechnology, } \\
\text { Heidelberg, Germany }\end{array}$ & $1: 200$ \\
\hline N-cadherin & Rabbit & $\begin{array}{l}\text { Ref. ab18203; Abcam, Cambridge, United } \\
\text { Kingdom }\end{array}$ & $1: 200$ \\
\hline $\mathrm{p} 21$ & Mouse & $\begin{array}{l}\text { Ref. SC-6246; Santa Cruz Biotechnology, } \\
\text { Heidelberg, Germany }\end{array}$ & $1: 100$ \\
\hline \multicolumn{4}{|c|}{ Primary antibodies used in western blot } \\
\hline Phospho-ERK 1/2 & Rabbit & $\begin{array}{l}\text { Ref. 4370S; Cell Signaling Technology, } \\
\text { Danvers, USA }\end{array}$ & $1: 2000$ \\
\hline Total-ERK 1/2 & Mouse & $\begin{array}{l}\text { Ref. 4696S; Cell Signaling Technology, } \\
\text { Danvers, USA }\end{array}$ & $1: 2000$ \\
\hline $\mathrm{N}$-cadherin & Rabbit & $\begin{array}{l}\text { Ref. ab18203; Abcam, Cambridge, United } \\
\text { Kingdom }\end{array}$ & $1: 1000$ \\
\hline$\beta$-actin & Goat & $\begin{array}{l}\text { Ref. sc1616; Santa Cruz Biotechnology, } \\
\text { Heidelberg, Germany }\end{array}$ & $1: 250$ \\
\hline \multicolumn{4}{|c|}{ Secondary antibody used in immunohistochemistry } \\
\hline Biotinylated anti-rabbit & Swine & Ref. EO35301-2; Dako, Glostrup, Denmark & $1: 200$ \\
\hline \multicolumn{4}{|c|}{ Secondary antibody used in immunofluorescence } \\
\hline $\begin{array}{l}\text { Anti-mouse } \operatorname{IgG}(\mathrm{H}+\mathrm{L}) \text {, Alexa } \\
\text { Fluor }^{\circledR} 488\end{array}$ & Goat & $\begin{array}{l}\text { Ref. 4408; Cell Signaling Technology, } \\
\text { Danvers, USA }\end{array}$ & $1: 1000$ \\
\hline $\begin{array}{l}\text { Anti-rabbit } \operatorname{IgG}(\mathrm{H}+\mathrm{L}) \text {, Alexa } \\
\text { Fluor }^{\circledR} 555\end{array}$ & Goat & $\begin{array}{l}\text { Ref. 4413; Cell Signaling Technology, } \\
\text { Danvers, USA }\end{array}$ & $1: 1000$ \\
\hline \multicolumn{4}{|c|}{ Secondary antibodies used in western blot } \\
\hline Anti-goat IgG-HRP & Donkey & $\begin{array}{l}\text { Ref. sc-2020; Santa Cruz Biotechnology, } \\
\text { Heidelberg, Germany }\end{array}$ & $1: 1000$ \\
\hline Anti-mouse IgG-HRP & Goat & Ref. 12-349; Merck-Millipore, California, USA & $1: 2000$ \\
\hline Anti-rabbit IgG-HRP & Goat & $\begin{array}{l}\text { Ref. ab6721; Abcam, Cambridge, United } \\
\text { Kingdom }\end{array}$ & $1: 2500$ \\
\hline
\end{tabular}

$I G F 2$ insulin-like growth factor 2, $B r d U$ 5-bromo-2-deoxyuridine, $E R K$ extracellular signal-regulated kinase, $H R P$ horseradish peroxidase, $I g$ immunoglobulin
(ITS) (Corning, NY, USA). The medium was changed three/four times per week and the cells were detached for sub-culturing with a $0.25 \%$ trypsinethylenediaminetetraacetic acid (EDTA) solution (SigmaAldrich, St Louis, MO, USA). Cell cultures were handled in a laminar flow chamber and maintained at $37{ }^{\circ} \mathrm{C}$ in an incubator (Heracell 150i, Thermo Scientific, Waltham, MA USA) with $5 \% \mathrm{CO}_{2}$. Before incubating cells with any of the used growth factors or inhibitors, a serum and ITS $2 \mathrm{~h}$ starvation was performed to reduce the basal signaling activity and washout the insulin from the media since insulin can signal through the IGF1-R [18] and so interfere with our results. The starvation time was optimized based on the need to balance the evaluation of the effects on signaling pathways analyzed while ensuring cell viability. All the experiments were also performed without serum or ITS, by the same reasons appointed before.

Cells were then incubated with 2 different IGF2 concentrations $(50 \mathrm{ng} / \mathrm{mL}$ and $100 \mathrm{ng} / \mathrm{mL})$ for $24 \mathrm{~h}$, except when the aim was to evaluate the activation of the MAPK/ extracellular signal-regulated kinases (ERK) pathway or the mTOR pathway. In those cases, the incubations were performed for 5, 10, and $20 \mathrm{~min}$.

In addition, as H295R cells in cell culture are capable of secreting IGF2 in amounts increasing along time [19], we decided not to exceed a total of $48 \mathrm{~h}$ of total culture time ( $24 \mathrm{~h}$ without treatment $+24 \mathrm{~h}$ with treatment) in order to mitigate the putative effect of autocrine IGF2 and maintain 
high cell viability rates in the control group (cells without IGF2).

IGF2 concentrations chosen were based on the previous knowledge that $\mathrm{H} 295 \mathrm{R}$ cells produce IGF2 and also on the fact that IGF2 levels in ACC can vary more than ten times $[12,19,20]$. So, the in vitro study was designed in order to attain a spectrum of IGF2 in the medium ranging from $5(50 \mathrm{ng} / \mathrm{mL})$ to 10 times $(100 \mathrm{ng} / \mathrm{mL})$, approximately. Moreover, the volume on the wells was adapted to ensure that the desired IGF2 concentration was achieved.

The MEK inhibitor (PD184352, Sigma-Aldrich) concentration used $(10 \mu \mathrm{M})$ was previously reported to significantly decrease the phospho-ERK in H295R cells [21]. For mTOR inhibitor (Rapamycin, Alfa Aesar, MA, USA), two concentrations (50 and $100 \mathrm{nM}$ ) were evaluated, using a mTOR Elisa Kit described below. The higher concentration showed to be more effective on the mTOR expression inhibition. Besides, this concentration was successfully used before in this cell type [22].

For cell proliferation, viability and metabolism, each treatment was replicated five times. The cell invasion, senescence, and $\mathrm{N}$-cadherin analysis were replicated three times.

\section{Cell proliferation assay}

H295R cells $\left(0.4 \times 10^{6}\right.$ cells/well $)$ were cultured in 24 well-plates with complete medium for $22 \mathrm{~h}$ followed by a $2 \mathrm{~h}$ period with serum and ITS depleted medium. H295R cells were then incubated for $24 \mathrm{~h}$ in the presence of IGF2 alone, IGF2 + MEK inhibitor (PD184352), IGF2 + mTOR inhibitor (Rapamycin) or IGF2 + MEK inhibitor + mTOR inhibitor. H295R cell proliferation was monitored by 5-bromo-2-deoxyuridine (BrdU, $10 \mu \mathrm{M}$, SigmaAldrich) incorporation over a $2 \mathrm{~h}$ period. Cultured cells were harvested by cyto-spinning, fixed in $4 \%$ paraformaldehyde (Merck Millipore, Darmstadt, Germany) followed by immunofluorescence for BrdU staining (Table 2). A minimum of 500 cells were counted at a 400x magnification.

\section{Cell viability assay}

H295R cells $\left(0.05 \times 10^{6}\right.$ cells/well $)$ were cultured in 96 well-plates with complete medium for $22 \mathrm{~h}$ followed by a 2$\mathrm{h}$ period with serum and ITS depleted medium. H295R cells were then incubated for $24 \mathrm{~h}$ with IGF2 alone, IGF2 + MEK inhibitor (PD184352), IGF2 + mTOR inhibitor (Rapamycin) or IGF2 + MEK inhibitor + mTOR inhibitor, in the presence of 10\% Alamar Blue (Bio-Rad AbD Serotec, Oxford, UK). Absorbance was measured at wavelengths of $570 \mathrm{~nm}$ and $595 \mathrm{~nm}$, at 0,12 and $24 \mathrm{~h}$. The \% of resazurin reduction was calculated using the following equation:

$\%$ Reduction $=\left(\frac{\operatorname{Eox}_{\lambda 2} x A_{\lambda 1}-\operatorname{Eox}_{\lambda 1} x A_{\lambda 2}}{\operatorname{Ered}_{\lambda 1} x A_{\text {blank } \lambda 2}-\operatorname{Ered}_{\lambda 2} x A_{\text {blank } \lambda 1}}\right) \times 100$,

where $\lambda 1=570 \mathrm{~nm}, \lambda 2=595 \mathrm{~nm}, \operatorname{Eox}_{1}=80,573, \operatorname{Eox}_{2}=$ 117,216, Ered $_{1}=155,667$ and Ered $_{2}=14,652$.

\section{p21 immunofluorescence}

H295R cells $\left(0.8 \times 10^{6}\right.$ cells $)$ were incubated in coverslips immersed in 6 well-plates with complete medium for $22 \mathrm{~h}$ followed by 2-hour period with serum and ITS depleted medium. H295R cells were then exposed to IGF2 with and without the pathway's inhibitors (Rapamycin for mTOR pathway inhibition and PD184352 for MAPK pathway inhibition). After $24 \mathrm{~h}$, the cells were fixed in $4 \%$ paraformaldehyde for $15 \mathrm{~min}$ before immunofluorescence was performed. The coverslips were incubated overnight at $4{ }^{\circ} \mathrm{C}$ with the primary antibody for p21 (Table 2), followed by the secondary antibody incubation for $45 \mathrm{~min}$ to allow p21 detection (Table 2). The slides were then counterstained with $1 \mu \mathrm{g} / \mathrm{ml}$ DAPI (Sigma-Aldrich). Coverslips were mounted in slides with mounting solution (90\% glycerol, $0.5 \% \mathrm{~N}$-propyl-gallate, $20 \mathrm{nM}$ Tris, $\mathrm{pH} 8$ ). A minimum of 500 cells were counted at a $\times 200$ magnification.

\section{Cell nucleus size}

After H295R cells incubation with IGF2, with and without the pathways inhibitors (Rapamycin for mTOR pathway inhibition and PD184352 for MAPK pathway inhibition), cells were stained with $1 \mu \mathrm{g} / \mathrm{ml}$ DAPI (Sigma-Aldrich) and the nucleus area was evaluated in a minimum of 100 cells for experimental condition, using the ImageJ software.

\section{Invasion assay}

To evaluate the invasion capacity of H295R cells incubated with different IGF2 concentrations, cell culture inserts with an $8.0 \mu \mathrm{m}$ pore size membrane (BD Biocoat 24-well Matrigel Chambers, BD Bioscience Bedford, MA, USA) were used according to the manufacturer's protocol. Matrigel-coated inserts were pre-incubated for $1 \mathrm{~h}$ with serum-free DMEM-F12, before H295R cells $\left(0.1 \times 10^{6}\right.$ cells $)$ were seeded in the upper chamber of the well and cultivated in the presence of IGF2. Medium supplemented with $30 \% \mathrm{Nu}$-serum was used as chemoattractant and so added into the bottom of the lower chamber in the 24-well plate. After $24 \mathrm{~h}$, the medium was collected, the membranes of the inserts were fixed with $70 \%$ ethanol and the cells were stained with $0.2 \%$ crystal violet for $10 \mathrm{~min}$, as previously described [23]. The 
membranes were then mounted on slides using entellan and the cells that invaded the membrane were observed and counted using an optical microscope (Zeiss AxioPlan microscope, Zeiss, Germany).

\section{$\mathrm{N}$-cadherin immunofluorescence}

The H295R cell $\left(0.4 \times 10^{6}\right.$ cells $)$ were incubated in coverslips immersed in 24-well-plates, with complete medium for $22 \mathrm{~h}$ followed by 2 -h period with serum and ITS depleted medium (NuSerum). H295R cells were then exposed to IGF2 for $24 \mathrm{~h}$, after which cells were fixed in $4 \%$ paraformaldehyde for $15 \mathrm{~min}$ before immunofluorescence was performed. The coverslips were incubated overnight at $4{ }^{\circ} \mathrm{C}$ with the primary antibody for $\mathrm{N}$ cadherin (Table 2), followed by the secondary antibody incubation for $2 \mathrm{~h}$ to allow $\mathrm{N}$-cadherin detection (Table 2). The slides were then mounted and counterstained with Vectashield hardset with Dapi (ref. H1500, Vector Laboratories, UK).

\section{Western blot}

After IGF2 incubation, cell proteins were extracted using RIPA buffer (ref: 20-188, Sigma-Aldrich, USA) with protease inhibitor (ref: 4693124001, Roche, Switzerland) and phosphatase inhibitor (ref: 4906845001, Roche). Extracted proteins were quantified using the Pierce ${ }^{\mathrm{TM}}$ BCA Protein Assay Kit (ref: 23225, ThermoFisher Scientific, USA). A total of $20 \mu \mathrm{g}$ of protein was heated at $95{ }^{\circ} \mathrm{C}$ for $10 \mathrm{~min}$, fractionated on a $12 \%$ sodium dodecyl sulfate-polyacrylamide gel electrophoresis (SDS-PAGE) and transferred to polyvinylidene difluoride membranes. The membranes were blocked in a Tris-buffered saline solution with $0.05 \%$ Tween 20 containing 5\% BSA (ref: A7906, Sigma- Aldrich) and incubated overnight at $4{ }^{\circ} \mathrm{C}$ with the primary antibodies, separately (Table 2 ). Mouse $\beta$-actin was used as protein loading control for $\mathrm{N}$-cadherin quantification. Immune-reactive proteins were detected separately using the respective secondary antibody (Table 2). Membranes were reacted with ECL detection (ref. 32209, GE Healthcare) system and read with the ChemiDoc $^{\text {TM }}$ XRS + System (Bio-Rad, UK). The densities of each band were obtained using the Quantity One Software (Bio-Rad, UK).

\section{mTOR Elisa}

After H295R cells incubation with different IGF2 concentrations, proteins were extracted and phospho-mTOR and total-mTOR expression were assessed using the RayBio $^{\circledast}$ Human and Mouse Phospho-mTOR (Ser2448) and Total mTOR ELISA Kit (PEL-mTOR-S2448-T-1,
RayBio, GA, USA), following the manufacturer's instructions.

\section{Nuclear magnetic resonance (NMR) spectroscopy}

${ }^{1} \mathrm{H}$ NMR spectroscopy (VNMRS $600 \mathrm{MHz}$, Varian, Inc. Palo Alto, CA) was used to determine metabolite concentrations in H295R cell culture media after IGF2 incubation. Sodium fumarate was used as internal reference $(6.50 \mathrm{ppm})$ to quantify the following metabolites (multiplet, ppm): lactate (doublet, 1.33); alanine (doublet, 1.45); pyruvate (singlet, 2.36); glutamine (triplet, 3.75) and H1- $\alpha$ glucose (doublet, 5.22) as previously described [24]. The relative areas of ${ }^{1} \mathrm{H}$ NMR resonances were quantified using the curve-fitting routine supplied with the NUTSpro ${ }^{\mathrm{TM}}$ NMR spectral analysis program (Acorn, Fremont, CA, USA) and the results were normalized to the number of cells present at the time when the media was collected.

\section{Statistical analysis}

All results are presented as mean \pm standard error (SE). D'Agostinho \& Pearson test was used to evaluate variables normality. For continuous variables that passed this test, one-way ANOVA test with the post-hoc Tukey test was used to compare the means of three groups. For the variables that did not pass the normality test, the Kruskal-Wallis with a Post-hoc Dunn's test was used. The correlations between continuous variables were evaluated using the Pearson Test. The diagnostic accuracy of IGF2 was evaluated using the receiver operating characteristic (ROC) curve. Statistical analysis was performed using the GraphPad Prism version 6.01 for Windows (GraphPad Software, La Jolla, CA, USA). The significance level was defined by a value of $p<0.05$.

\section{Results}

\section{IGF2 in tumor and normal human adrenocortical tissues}

\section{The expression of IGF2 is significantly higher in ACC}

The percentage of stained area for IGF2 was significantly higher in ACC $(35.97 \pm 1.38)$ compared to ACAn (16.79 \pm 2.09) and N-AG (13.45 \pm 1.94$), p<0.001$ (Fig. 1a-d). ROC Curve analysis showed an area under the curve (AUC) of 1.00 for discrimination between ACC and ACAn, with a specificity and sensibility of $100 \%$, using a cut-off of $27.11 \%$ of IGF2 stained area (Fig. 1e). No correlation was observed between IGF2 and p53 expression $(R=0.47)$. Furthermore, IGF2 expression was not correlated with the $\beta$-catenin localization, in ACC (Table 1). 


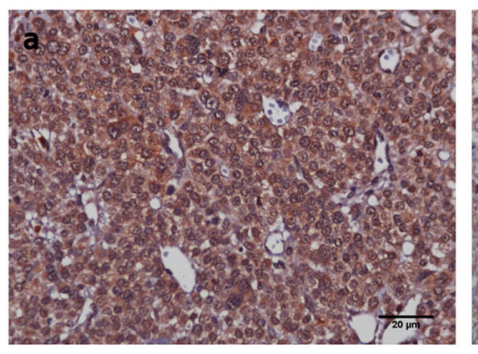

d

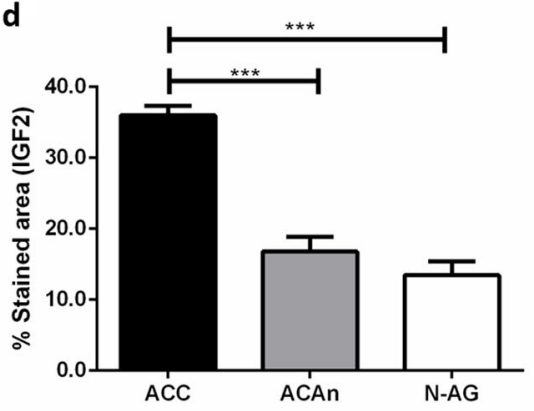

Fig. 1 Immunohistochemistry staining for IGF2 $($ Scale $=20 \mu \mathrm{m})$ in adrenocortical carcinoma (ACC) $\mathbf{a}$, non-functioning adrenocortical adenoma (ACAn) b, and normal adrenal gland (N-AG) c. Graphic representation of the percentage of area staining for IGF2 in the e

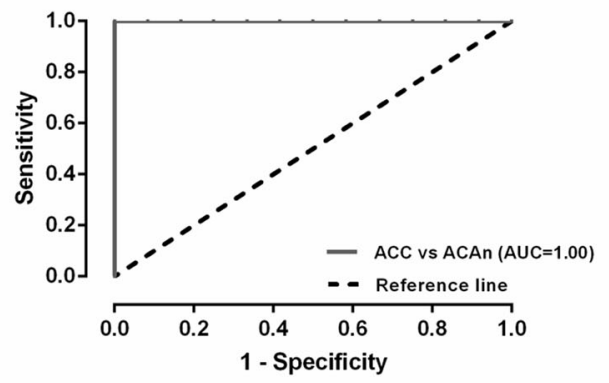

studied groups $\mathbf{d}$ and ROC curves with the respective area under the curve (AUC) to compare carcinomas with adenomas e (ANOVA: $* * * p<0.001)$
Fig. 2 H295R cells viability a and proliferation $\mathbf{b}$ after incubation without or with IGF2 at the concentrations of 50 and $100 \mathrm{ng} / \mathrm{mL}$ for $24 \mathrm{~h}$ (ANOVA: $* p<0.05)$ a

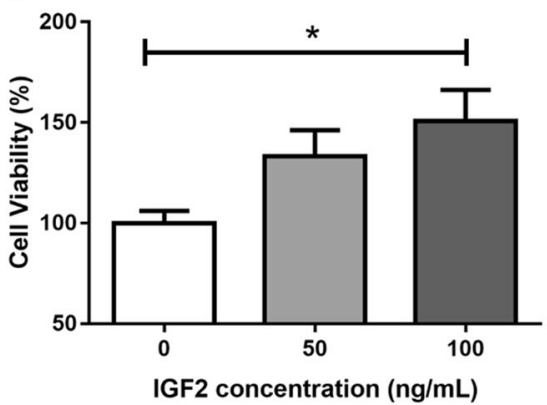

b

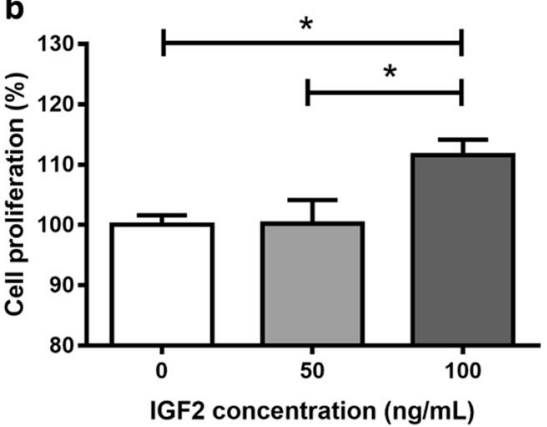

\section{In vitro analysis of the influence of IGF2 in the H295R proliferation, viability, invasion, and metabolism}

\section{A high IGF2 concentration increases H295R proliferation and viability}

H295R incubation with the highest IGF2 concentration tested $(100 \mathrm{ng} / \mathrm{mL})$ led to a significant increase in cell proliferation $(111.6 \pm 2.56 \%)$ after $24 \mathrm{~h}$ when compared to the cells incubated with the $50 \mathrm{ng} / \mathrm{mL}$ concentration $(100.2 \pm 3.93 \%)$ and to the cells that were not supplemented with IGF2 $(100.0 \pm 1.61 \% ; p<0.05)$. IGF2 $(100 \mathrm{ng} / \mathrm{mL})$ also significantly increased cell viability $(150.8 \pm 15.40 \%)$ when compared to the control $(100.0 \pm$ $6.11 \% ; p<0.05$ ) (Fig. 2).

\section{IGF2 increases both phospho-ERK and phospho-mTOR expression}

Incubation with both concentrations of IGF2 led to a rapid increase of the phospho-ERK expression $(5 \mathrm{~min}: 50 \mathrm{ng} / \mathrm{mL}$ : $266.6 \pm 138.8$ : $100 \mathrm{ng} / \mathrm{mL}: \quad 198.2 \pm 18.78$ ) (Fig. 3a). Phospho-ERK expression was stabilized thereafter with the IGF2 concentration of $50 \mathrm{ng} / \mathrm{mL}$, during the study time (5, 10 , and $20 \mathrm{~min}$ ), while the concentration of $100 \mathrm{ng} / \mathrm{mL}$ led to higher levels of phospho-ERK expression after $10 \mathrm{~min}$ of incubation $(584.7 \pm 212.3)$ followed by a subsequent decrease after this time point (20 min:296.2 \pm 35.76$)$ (Fig. 3a).

Incubation with $100 \mathrm{ng} / \mathrm{mL}$ of IGF2 led to an increase of the phospho-mTOR expression, at $5 \mathrm{~min}(0 \mathrm{~min}: 100.0 \pm$ 0.18 ; $5 \mathrm{~min}$ : $113.0 \pm 0.07$ ), followed by a subsequent 
Fig. 3 Relative phospho-ERK expression a and phosphomTOR expression $\mathbf{b}$, after IGF2 incubation at the concentrations of 50 and $100 \mathrm{ng} / \mathrm{mL}$ for 5,10 , and $20 \mathrm{~min}$
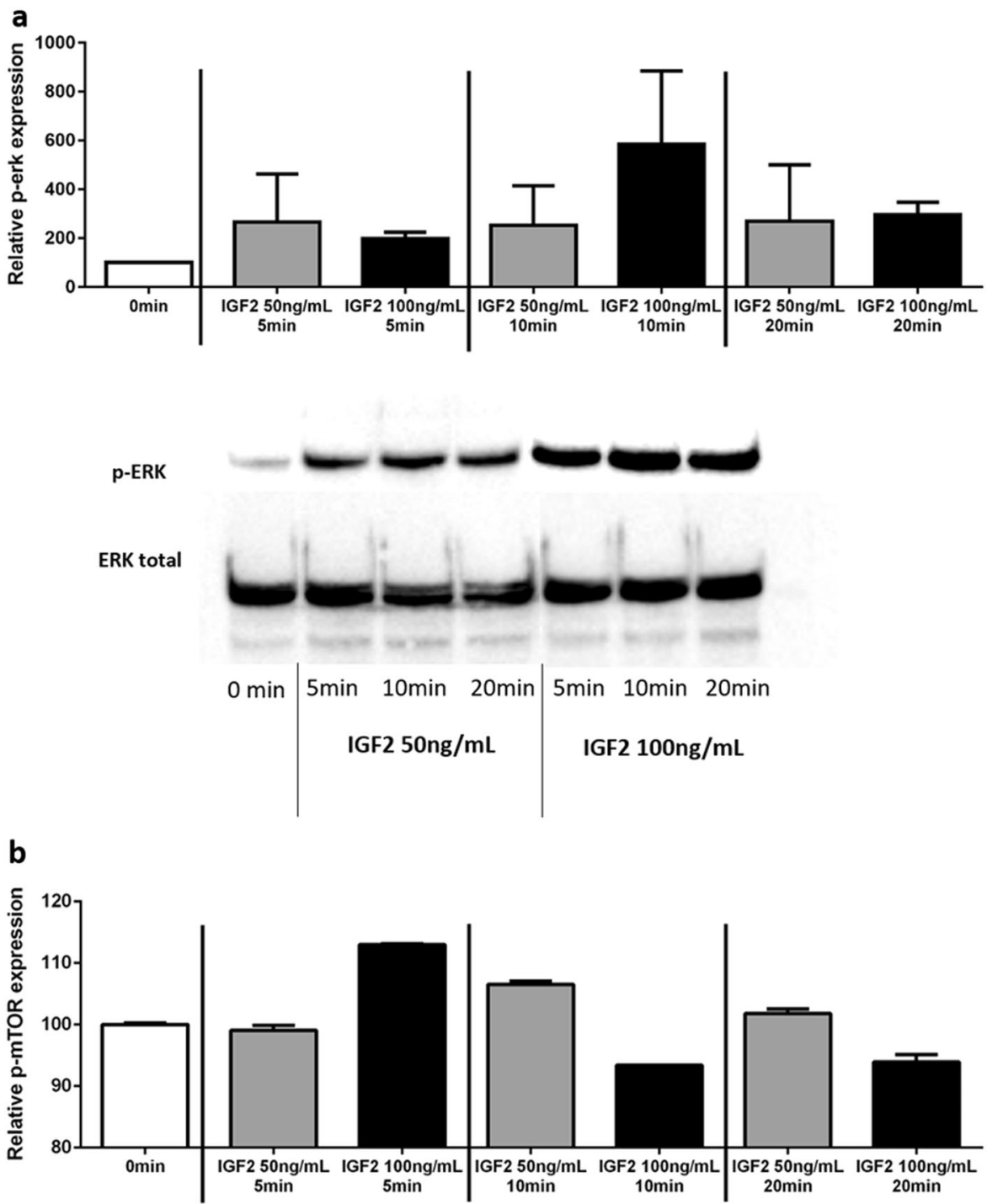

decrease after this time point (Fig. 3b). IGF2 at $50 \mathrm{ng} / \mathrm{mL}$ only slightly increased the phospho-mTOR expression after 10 min of incubation (113.0 \pm 0.07 , Fig. $3 b)$.

\section{mTOR inhibition reverts IGF2 triggered viability}

Co-incubation of IGF2 with the mTOR inhibitor blocked the IGF2-stimulated viability (IGF2 $100 \mathrm{ng} / \mathrm{mL}: 133.1 \pm$ 11.40; IGF2 $100 \mathrm{ng} / \mathrm{mL}$ + Rapamycin $100 \mathrm{nM:} 104.4 \pm$ 2.62) (Fig. 4a) while MEK inhibitor did not influence it (Fig. 4a).

\section{MEK and mTOR inhibition reverts IGF2 triggered proliferation}

Co-incubation of IGF2 with a MEK inhibitor blocked the IGF2-stimulated proliferation (IGF2 $100 \mathrm{ng} / \mathrm{mL}: 110.9 \pm$ 3.48; IGF2 $100 \mathrm{ng} / \mathrm{mL}+$ PD184532 $10 \mu \mathrm{M}$ : $95.78 \pm 5.10$ )
(Fig. 4b). Similar results were obtained using the mTOR inhibitor (IGF2 $100 \mathrm{ng} / \mathrm{mL}$ : $110.9 \pm 3.48$; IGF2 $100 \mathrm{ng} / \mathrm{mL}$ + Rapamycin $100 \mathrm{nM}$ : $98.41 \pm 3.23$ ) (Fig. 4b). MEK and mTOR inhibitor have a cumulative effect on the cell proliferation leading to a reduction of the proliferation of almost 50\% when compared with the control group (control: $100.2 \pm 1.31$; IGF2 $100 \mathrm{ng} / \mathrm{mL}$ + Rapamycin $100 \mathrm{nM}$ + PD184532 $10 \mu \mathrm{M}: 7.76 \pm 3.28$ ).

\section{mTOR and MEK inhibitors did not influenced H295R cells senescence}

p21-positivivity, a cell senescence marker [25] was present in a low number of cells $(<5 \%)$ independently of the study group. Besides that, the number of $\mathrm{p} 21$ positive cells did not vary with the presence of mTOR and/or MEK inhibitors (Supplementary file 1). The nucleus size was also similar in all the experimental groups (Supplementary file 1). 
Fig. 4 Cell viability a and proliferation $\mathbf{b}$ after treatment with IGF2 $(100 \mathrm{ng} / \mathrm{mL})$ with and without the MAPK and mTOR inhibitors $(100 \mathrm{nM}$ of Rapamycin for mTOR pathway inhibition and $10 \mathrm{nM}$ of PD184352 for MAPK pathway inhibition) (ANOVA: $* p<0.05$ ) a

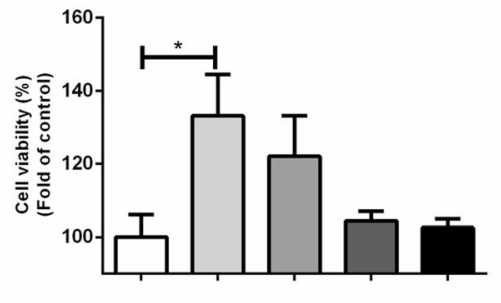

b

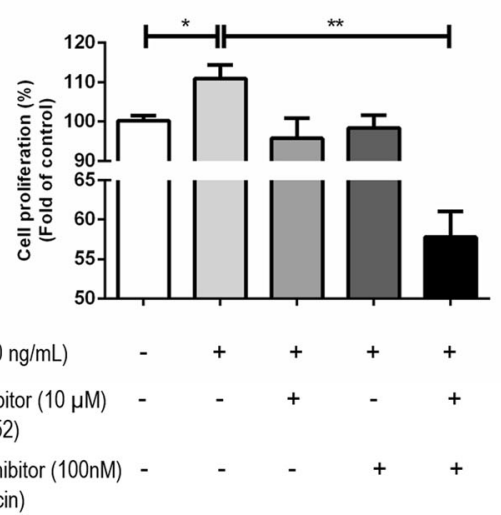

\section{IGF2 does not influence cell invasion capacity}

H295R cells invasion capacity was not influenced by IGF2 incubation. Besides that, IGF2 did not influence H295R cells N-cadherin expression (Fig. 5).

\section{IGF2 incubation at a concentration of $50 \mathrm{ng} / \mathrm{mL}$ decreased} glutamine consumption

Glutamine consumption by H295R cells was significantly lower after IGF2 incubation at a concentration of $50 \mathrm{ng} / \mathrm{mL}$ $\left(0.03 \pm 0.01 \mu \mathrm{mol} / 10^{6}\right.$ cells $)$ compared to control $(0.07 \pm$ $0.01 \mu \mathrm{mol} / 10^{6}$ cells, $\left.p<0.01\right)$ or to cells incubated with the IGF2 concentration of $100 \mathrm{ng} / \mathrm{mL}\left(0.06 \pm 0.01 \mu \mathrm{mol} / 10^{6}\right.$ cells, $p<0.05$, Fig. 6). Besides that, IGF2 dose-dependently increased the lactate/pyruvate ratio $(0 \mathrm{ng} / \mathrm{mL}:-30,43 \pm$ 25.70; $50 \mathrm{ng} / \mathrm{mL}: 49.68 \pm 12.25 ; 100 \mathrm{ng} / \mathrm{mL}: 96.14 \pm 30.27$, Fig.6f).

Glucose consumption and pyruvate, lactate and alanine production were not significantly influenced by IGF2 incubation (Fig. 6).

\section{Discussion}

The IGF2 system represents a crucial pathway in the tumor biology of ACC and was considered an attractive target for the treatment of these tumors [8]. IGF2 protein expression was found to be $8-80$ fold higher in ACC when compared to the N-AG or ACA, although the biological differences between high and low IGF2 expressing ACC have not yet been well characterized [11-16]. In order to gain further insight into the role of IGF2 in ACC pathogenesis, after having analyzed the IGF2 expression in different ACT and $\mathrm{N}-\mathrm{AG}$, we have evaluated the effects of IGF2 in some important hallmarks of cancer, including cell proliferation, viability, invasion, and metabolism in vitro in a human adrenocortical cancer cell line.
As previously reported, IGF2 expression was found to be significantly higher in ACC compared with ACA $[11,14,15,17,26]$. Besides that, our study showed that IGF2 presents a $100 \%$ of specificity and sensitivity to distinguish ACC from ACAn. So, using a computerized morphometric analysis of IGF2 expression may be used as a biomarker for the differential diagnosis between ACA and ACC. Thus, the potential use of IGF2 expression as a valuable diagnostic marker is herein demonstrated, whether this molecular marker could also provide additional information on the tumor biological behavior and disease progression, so that this could be used as a prognostic marker as well, is currently unknown. Nevertheless, in a previous work by other authors, the percentage of IGF2 stained cells was not shown to influence ACC survival [11].

Since $\beta$-catenin and p53 have been demonstrated to have an important role in ACC biology, we decided to assess whether there was a correlation between IGF2 and those proteins' expression. Although no mutational analysis was performed in this study, a small percentage of ACC exhibited a very high p53 expression due to accumulation of this protein in the cell, which is suggestive of the presence of p53 mutations [27]. Besides that, abnormal $\beta$-catenin localization i.e., in the cytoplasm and/or the cell nucleus instead of the normal localization at the cell membrane was also evaluated [28]. Our study showed that IGF2 expression in ACC is not correlated either with $\beta$ -catenin or with p53 status.

The high variability in IGF2 protein expression in ACC observed by several authors, raises the hypothesis that this could be reflected in distinct biological behaviors. To test this hypothesis a human adrenocortical carcinoma cell line (H295R) was used to assess the influence of IGF2 in several cancer hallmarks.

IGF2 at the higher concentration tested increased H295R cell proliferation and viability. Since the same IGF2 concentration also increased phospho-ERK and phosphomTOR expression, we decided to investigate whether 
a
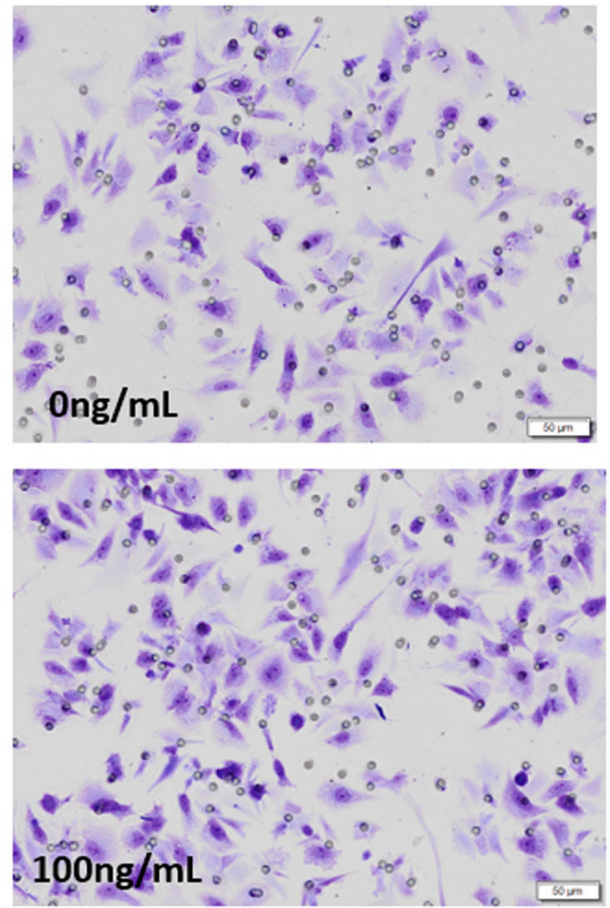

b

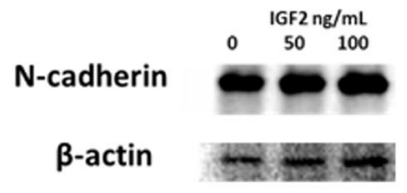

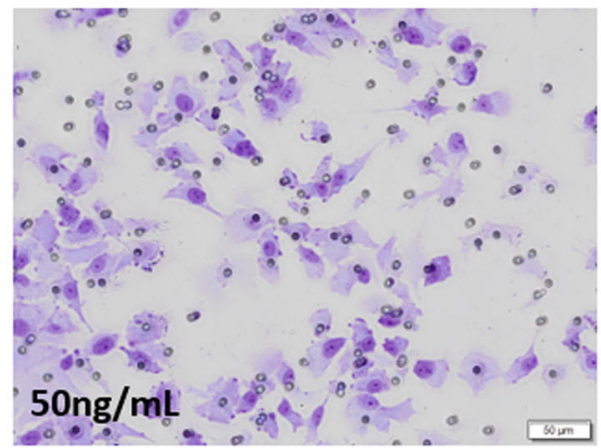

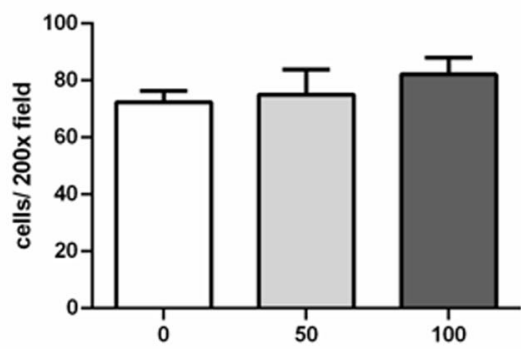

IGF2 concentration $(\mathrm{ng} / \mathrm{mL})$
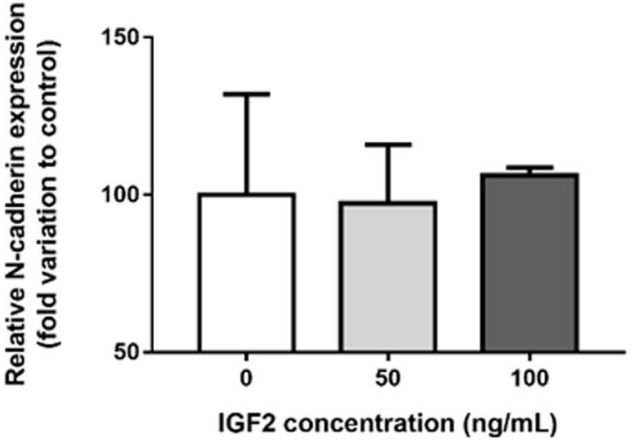
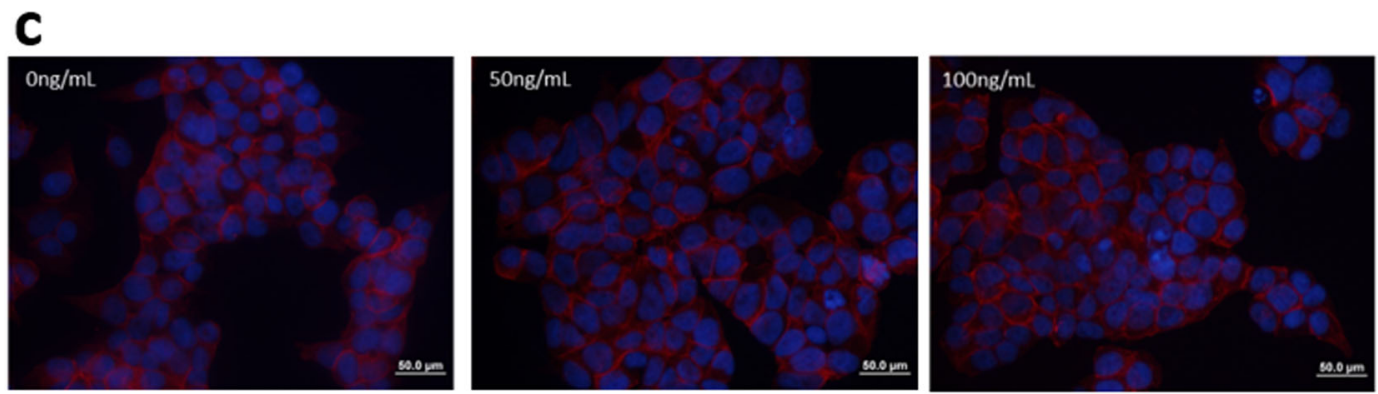

Fig. 5 Matrigel membrane invaded with H295R cells a. N-cadherin expression after $24 \mathrm{~h}$ incubation with IGF2 at the 50 and $100 \mathrm{ng} / \mathrm{mL}$ concentrations evaluated by western blot $\mathbf{b}$ and immunofluorescence $\mathbf{c}$

MAPK/ERK or mTOR pathways could be responsible for the increased cell proliferation and viability. The use of the MEK inhibitor was only able to revert IGF2 triggered cell proliferation, while cell viability was virtually unaltered. On the other side, mTOR inhibition was able to revert both IGF2 triggered cell proliferation and viability. These data supports that although both pathways are triggered by IGF2 binding to IGF1R [8], MAPK/ERK pathway is involved in the proliferative increment but does not seem to be involved in mediating the IGF2 effects in cell viability, while PI3K/ $\mathrm{Akt} / \mathrm{mTOR}$ pathway seems to be involved in the regulation of both processes. 

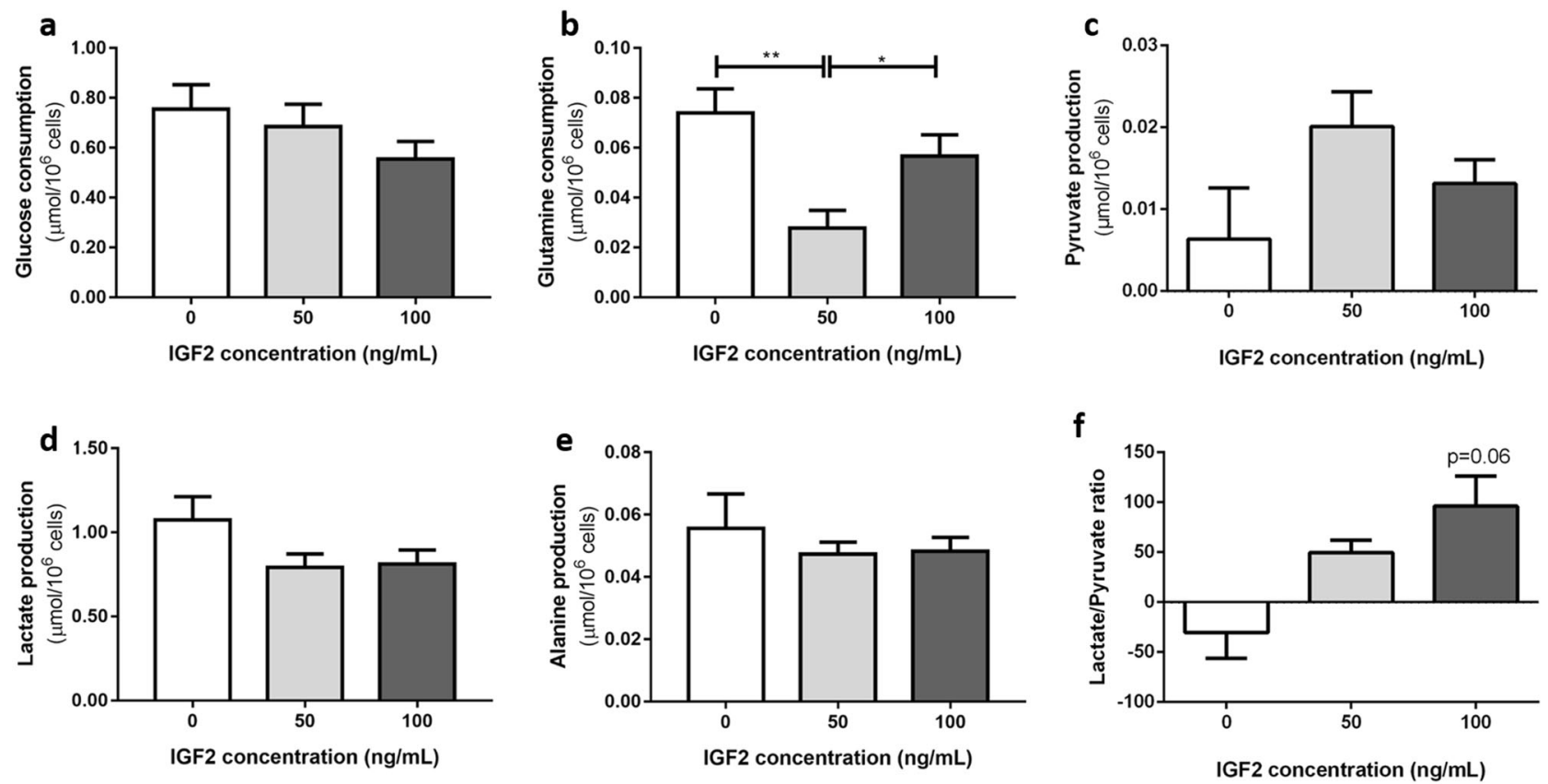

Fig. 6 Glucose $\mathbf{a}$ and glutamine $\mathbf{b}$ consumption; pyruvate $\mathbf{c}$, lactate $\mathbf{d}$ and alanine $\mathbf{e}$ production; lactate/pyruvate ratio $\mathbf{f}$ after IGF2 incubation at the concentrations of 50 and $100 \mathrm{ng} / \mathrm{mL}$ (ANOVA: ${ }^{*} p<0.05 ; * *<<0.01 ; p=0.06: 0 \mathrm{ng} / \mathrm{mL}$ vs $100 \mathrm{ng} / \mathrm{mL}$ )

Similarly, previous preclinical studies using different mTOR inhibitors also showed a decrease in ACC cell proliferation and ACC xenographs growth [29-32]. Unfortunately, despite these promising preclinical findings, patients with advanced ACC treated with a mTOR inhibitor (everolimus) showed no clinically significant benefits [33]. Some studies proposed that other IGF1R signaling pathways, such as MAPK/ERK pathway could be activated during the treatment in order to overcome the mTOR inhibitors effects [30, 33]. In our study, we showed that the combination of both inhibitors had a powerful effect reducing H295R cells proliferation and so, it supports the hypothesis that, MAPK/ERK and mTOR inhibitors combination could be a possible treatment for ACC that should be tested in the future.

Neither matrigel invasion nor $\mathrm{N}$-cadherin expression were affected in H295R cells treated with IGF2. These results point out that IGF2 does not seem to affect cell invasiveness and in fact are consistent with reports that the overall and the disease-free survival in ACC patients is unrelated to IGF2 expression [11].

Finally, our data show that IGF2 is able to interfere in ACC cell metabolism by dose-dependently increasing the lactate/piruvate ratio that is a robust indicator of the anaerobic metabolism and the redox status of the tissue. Besides that, different IGF2 concentrations influenced differentially the glutamine consumption. Glutamine is known to enter the cell through the Alanine-Serine-Cysteine transporter (ASCT2). When inside the cell, glutamine by itself can contribute to nucleotide biosynthesis or it can suffer glutaminolysis, a metabolic pathway in which glutamine is catabolized to generate ATP and lactate. For that glutamine is initially converted by glutaminase, into glutamate which is then converted to $\alpha$-ketoglutarate, a tricarboxylic acid (TCA) cycle intermediate, to produce both ATP and anabolic carbons for the de novo synthesis of amino acids, nucleotides, and lipids [34, 35]. IGF2 at a lower concentration $(50 \mathrm{ng} / \mathrm{mL})$ seems to lead to a compensatory balance between the anaerobic metabolism and glutamine consumption, as the anaerobic metabolism is increased while glutaminolysis decreases. IGF2 at a higher concentration $(100 \mathrm{ng} / \mathrm{mL})$ leads to similar levels of anaerobic metabolism with increased levels of glutamine consumption when compared to the lower concentration $(50 \mathrm{ng} / \mathrm{mL})$, suggesting that at a higher concentration IGF2 leads to cumulative effects on both pathways instead of compensatory.

The major limitation of this study is the small number of tumor samples that could be used and the fact that all the functional studies are based on a single cell model. This limitation was rather inevitable as ACC are relatively rare and H295R is the only well-characterized cell line that can be used as a model for this malignancy. In order to overcome this limitation, it is our plan to perform ACC primary cell cultures to validate these results in the future. Besides that, H295R cells have a specific genetic profile that includes the presence of beta-catenin protein accumulation associated with a point mutation of Ser 45 in exon 3 and so it 
must be stressed that these results may only be applied to tumors with this characteristic.

In conclusion, our results demonstrate that morphometric computerized analysis of may possibly be used in the clinical setting for the differential diagnosis between adrenocortical carcinomas and non-functioning adenomas. Moreover, IGF2 was demonstrated to influence adrenocortical cancer cell proliferation, metabolism, and viability, but not cell invasiveness. Altogether, these data suggest that different IGF2 concentrations in ACC can be responsible for different biological behaviors.

Funding This study was funded by the Foundation for Science and Technology (FCT) (PTDC/MEC-ONC/31384/2017). Unit for Multidisciplinary Research in Biomedicine (UMIB) is funded by grants from FCT (UID/ Multi/00215/2013).

\section{Compliance with ethical standards}

Conflict of interest The authors declare that they have no conflict of interest.

Ethical approval All procedures performed in studies involving human participants were in accordance with the ethical standards of the institutional and/or national research committee (Ethics Committee of the Centro Hospitalar São João - Porto, Portugal) and with the 1964 Helsinki declaration and its later amendments or comparable ethical standards.

Publisher's note: Springer Nature remains neutral with regard to jurisdictional claims in published maps and institutional affiliations.

Open Access This article is distributed under the terms of the Creative Commons Attribution 4.0 International License (http://crea tivecommons.org/licenses/by/4.0/), which permits unrestricted use, distribution, and reproduction in any medium, provided you give appropriate credit to the original author(s) and the source, provide a link to the Creative Commons license, and indicate if changes were made.

\section{References}

1. T. Else, A.C. Kim, A. Sabolch, V.M. Raymond, A. Kandathil, E. M. Caoili, S. Jolly, B.S. Miller, T.J. Giordano, G.D. Hammer, Adrenocortical carcinoma. Endocr. Rev. 35(2), 282-326 (2014). https://doi.org/10.1210/er.2013-1029

2. D. Pignatelli, Adrenal Cortex Tumors and Hyperplasias. INTECH Open Access Publisher, (2011)

3. P.S. Soon, K.L. McDonald, B.G. Robinson, S.B. Sidhu, Molecular markers and the pathogenesis of adrenocortical cancer. Oncologist 13(5), 548-561 (2008). https://doi.org/10.1634/ theoncologist.2007-0243

4. T. Lehmann, T. Wrzesinski, The molecular basis of adrenocortical cancer. Cancer Genet. 205(4), 131-137 (2012). https://doi.org/10. 1016/j.cancergen.2012.02.009

5. M. Fassnacht, M. Kroiss, B. Allolio, Update in adrenocortical carcinoma. J. Clin. Endocrinol. Metab. 98(12), 4551-4564 (2013). https://doi.org/10.1210/jc.2013-3020

6. S. Zheng, A.D. Cherniack, N. Dewal, R.A. Moffitt, L. Danilova, B.A. Murray, A.M. Lerario, T. Else, T.A. Knijnenburg, G. Ciriello, S. Kim, G. Assie, O. Morozova, R. Akbani, J. Shih, K.A.
Hoadley, T.K. Choueiri, J. Waldmann, O. Mete, A.G. Robertson, H.T. Wu, B.J. Raphael, L. Shao, M. Meyerson, M.J. Demeure, F. Beuschlein, A.J. Gill, S.B. Sidhu, M.Q. Almeida, M.C. Fragoso, L.M. Cope, E. Kebebew, M.A. Habra, T.G. Whitsett, K.J. Bussey, W.E. Rainey, S.L. Asa, J. Bertherat, M. Fassnacht, D.A. Wheeler; Cancer Genome Atlas Research, N., G.D. Hammer, T.J. Giordano, R.G. Verhaak, Comprehensive Pan-Genomic Characterization of Adrenocortical Carcinoma. Cancer Cell 29(5), 723-736 (2016). https://doi.org/10.1016/j.ccell.2016.04.002

7. B. Altieri, A. Colao, A. Faggiano, The role of insulin-like growth factor system in the adrenocortical tumors. Minerva Endocrinol. 44 (1), 43-57 (2019). https://doi.org/10.23736/s0391-1977.18.02882-1

8. T.C. Ribeiro, A.C. Latronico, Insulin-like growth factor system on adrenocortical tumorigenesis. Mol. Cell Endocrinol. 351(1), 96-100 (2012). https://doi.org/10.1016/j.mce.2011.09.042

9. W.T. Iams, C.M. Lovly, Molecular pathways: clinical applications and future direction of insulin-like growth factor-1 receptor pathway blockade. Clin. Cancer Res 21(19), 4270-4277 (2015). https://doi.org/10.1158/1078-0432.CCR-14-2518

10. C. Livingstone, IGF2 and cancer. Endocr. Relat. Cancer 20(6), R321-R339 (2013). https://doi.org/10.1530/ERC-13-0231

11. M. Guillaud-Bataille, B. Ragazzon, A. de Reynies, C. Chevalier, I. Francillard, O. Barreau, V. Steunou, J. Guillemot, F. Tissier, M. Rizk-Rabin, F. Rene-Corail, A. Al Ghuzlan, G. Assie, X. Bertagna, E. Baudin, Y. Le Bouc, J. Bertherat, E. Clauser, IGF2 promotes growth of adrenocortical carcinoma cells, but its overexpression does not modify phenotypic and molecular features of adrenocortical carcinoma. PLoS ONE 9(8), e103744 (2014). https://doi.org/10.1371/journal.pone.0103744

12. N. Boulle, A. Logie, C. Gicquel, L. Perin, Y. Le Bouc, Increased levels of insulin-like growth factor II (IGF-II) and IGF-binding protein-2 are associated with malignancy in sporadic adrenocortical tumors. J. Clin. Endocrinol. Metab. 83(5), 1713-1720 (1998). https://doi.org/10.1210/jcem.83.5.4816

13. V. Ilvesmaki, A.I. Kahri, P.J. Miettinen, R. Voutilainen, Insulinlike growth factors (IGFs) and their receptors in adrenal tumors: high IGF-II expression in functional adrenocortical carcinomas. J. Clin. Endocrinol. Metab. 77(3), 852-858 (1993). https://doi.org/ 10.1210/jcem.77.3.8370710

14. P.S. Soon, A.J. Gill, D.E. Benn, A. Clarkson, B.G. Robinson, K. L. McDonald, S.B. Sidhu, Microarray gene expression and immunohistochemistry analyses of adrenocortical tumors identify IGF2 and Ki-67 as useful in differentiating carcinomas from adenomas. Endocr. Relat. Cancer 16(2), 573-583 (2009). https:// doi.org/10.1677/ERC-08-0237

15. A. Schmitt, P. Saremaslani, S. Schmid, V. Rousson, M. Montani, D.M. Schmid, P.U. Heitz, P. Komminoth, A. Perren, IGFII and MIB1 immunohistochemistry is helpful for the differentiation of benign from malignant adrenocortical tumours. Histopathology 49 (3), 298-307 (2006). https://doi.org/10.1111/j.1365-2559.2006. 02505.x

16. L.A. Erickson, L. Jin, T.J. Sebo, C. Lohse, V.S. Pankratz, M.L. Kendrick, J.A. van Heerden, G.B. Thompson, C.S. Grant, R.V. Lloyd, Pathologic features and expression of insulin-like growth factor-2 in adrenocortical neoplasms. Endocr. Pathol. 12(4), 429-435 (2001)

17. S.S. Pereira, T. Morais, M.M. Costa, M.P. Monteiro, D. Pignatelli, The emerging role of the molecular marker p27 in the differential diagnosis of adrenocortical tumors. Endocr. Connect 2(3), 137-145 (2013). https://doi.org/10.1530/EC-13-0025

18. P. De Meyts, The insulin receptor and its signal transduction network. In: Endotext [Internet]. MDText. com, Inc., (2016)

19. A. Logie, N. Boulle, V. Gaston, L. Perin, P. Boudou, Y. Le Bouc, C. Gicquel, Autocrine role of IGF-II in proliferation of human adrenocortical carcinoma NCI H295R cell line. J. Mol. Endocrinol. 23(1), 23-32 (1999) 
20. M. Guillaud-Bataille, B. Ragazzon, A. de Reyniès, C. Chevalier, I. Francillard, O. Barreau, V. Steunou, J. Guillemot, F. Tissier, M. Rizk-Rabin, F. René-Corail, A. Al Ghuzlan, G. Assié, X. Bertagna, E. Baudin, Y. Le Bouc, J. Bertherat, E. Clauser, IGF2 promotes growth of adrenocortical carcinoma cells, but its overexpression does not modify phenotypic and molecular features of adrenocortical carcinoma. PLoS One 9(8), e103744-e103744 (2014). https://doi.org/10.1371/journal.pone.0103744

21. S.S. Pereira, M.P. Monteiro, M.M. Costa, J. Ferreira, M.G. Alves, P. F. Oliveira, I. Jarak, D. Pignatelli, MAPK/ERK pathway inhibition is a promising treatment target for adrenocortical tumors. J. Cell. Biochem. 120(1), 894-906 (2019). https://doi.org/10.1002/jcb.27451

22. H. Su, Y. Gu, F. Li, Q. Wang, B. Huang, X. Jin, G. Ning, F. Sun, The PI3K/AKT/mTOR Signaling pathway is overactivated in primary aldosteronism. PLos ONE 8(4), e62399 (2013). https:// doi.org/10.1371/journal.pone.0062399

23. C.R. Justus, N. Leffler, M. Ruiz-Echevarria, L.V. Yang, In vitro cell migration and invasion assays. J Vis $\operatorname{Exp}(88)$ (2014). https:// doi.org/10.3791/51046

24. M.G. Alves, P.J. Oliveira, R.A. Carvalho, Substrate selection in hearts subjected to ischemia/reperfusion: role of cardioplegic solutions and gender. NMR Biomed. 24(9), 1029-1037 (2011). https://doi.org/10.1002/nbm.1640

25. J. Campisi, F. d'Adda di Fagagna, Cellular senescence: when bad things happen to good cells. Nat. Rev. Mol. cell Biol. 8(9), 729-740 (2007). https://doi.org/10.1038/nrm2233

26. C. Gicquel, N. Boulle, A. Logie, N. Bourcigaux, V. Gaston, Y. Le Bouc, [Involvement of the IGF system in the pathogenesis of adrenocortical tumors]. Ann. d.'Endocrinol. 62(2), 189-192 (2001)

27. R. Libè, L. Groussin, F. Tissier, C. Elie, F. René-Corail, A. Fratticci, E. Jullian, P. Beck-Peccoz, X. Bertagna, C. Gicquel, J. Bertherat, Somatic <em $>$ TP53</em> Mutations Are Relatively Rare among Adrenocortical Cancers with the Frequent $17 \mathrm{p} 13$ Loss of Heterozygosity. Clin. Cancer Res. 13(3), 844-850 (2007). https://doi.org/10.1158/1078-0432.Ccr-06-2085

28. F. Tissier, C. Cavard, L. Groussin, K. Perlemoine, G. Fumey, A. M. Hagnere, F. Rene-Corail, E. Jullian, C. Gicquel, X. Bertagna, M.C. Vacher-Lavenu, C. Perret, J. Bertherat, Mutations of betacatenin in adrenocortical tumors: activation of the Wnt signaling pathway is a frequent event in both benign and malignant adrenocortical tumors. Cancer Res 65(17), 7622-7627 (2005). https:// doi.org/10.1158/0008-5472.Can-05-0593

29. M.C. De Martino, P.M. van Koetsveld, R.A. Feelders, D. SprijMooij, M. Waaijers, S.W. Lamberts, W.W. de Herder, A. Colao, R. Pivonello, L.J. Hofland, The role of mTOR inhibitors in the inhibition of growth and cortisol secretion in human adrenocortical carcinoma cells. Endocr. Relat. Cancer 19(3), 351-364 (2012). https://doi.org/10.1530/erc-11-0270

30. M.C. De Martino, P.M. van Koetsveld, R.A. Feelders, W.W. de Herder, F. Dogan, J. Janssen, D. Hofste Op Bruinink, C. Pivonello, A.M. Waaijers, A. Colao, R.R. de Krijger, R. Pivonello, L.J. Hofland, IGF and mTOR pathway expression and in vitro effects of linsitinib and mTOR inhibitors in adrenocortical cancer. Endocrine 64(3), 673-684 (2019). https://doi.org/10.1007/ s12020-019-01869-1

31. M. Doghman, A.E. Wakil, B. Cardinaud, E. Thomas, J. Wang, W. Zhao, M.H.P.-D. Valle, B.C. Figueiredo, G.P. Zambetti, E. Lalli, Regulation of insulin-like growth factor-mammalian target of rapamycin signaling by microRNA in childhood adrenocortical tumors. Cancer Res. 70, 4666-4675 (2010)

32. M.C. De Martino, R.A. Feelders, W.W. de Herder, P.M. van Koetsveld, F. Dogan, J.A. Janssen, A.M. Waaijers, C. Pivonello, S.W. Lamberts, A. Colao, R.R. de Krijger, R. Pivonello, L.J. Hofland, Characterization of the mTOR pathway in human normal adrenal and adrenocortical tumors. Endocr. Relat. Cancer 21(4), 601-613 (2014). https://doi.org/10.1530/erc-13-0112

33. M. Fraenkel, M. Gueorguiev, D. Barak, A. Salmon, A.B. Grossman, D.J. Gross, Everolimus therapy for progressive adrenocortical cancer. Endocrine 44(1), 187-192 (2013). https://doi.org/10. 1007/s12020-013-9878-1

34. L. Jin, G.N. Alesi, S. Kang, Glutaminolysis as a target for cancer therapy. Oncogene 35(28), 3619-3625 (2016). https://doi.org/10. 1038/onc.2015.447

35. B.J. Altman, Z.E. Stine, C.V. Dang, From Krebs to clinic: glutamine metabolism to cancer therapy. Nat. Rev. Cancer 16(10), 619-634 (2016). https://doi.org/10.1038/nrc.2016.71 